\title{
THE MEDIATING ROLE OF PROCEDURAL JUSTICE IN RESPONSES TO PROMOTION DECISIONS ${ }^{1}$
}

\author{
Silvia Bagdadli \\ Department of Organization and Information System \\ Bocconi University, Viale Isonzo 23, 20135 Milan, Italy \\ silvia.bagdadli@uni-bocconi.it \\ Quinetta Roberson \\ Human Resource Studies \\ Cornell University, 393 Ives Hall, Ithaca, NY 14853-3901, USA
}

Francesco Paoletti

Department of Human Sciences for Education

University of Milano - Bicocca, Piazza dell'Ateneo Nuovo 1, 20126 Milan, Italy

\begin{abstract}
This study used structural equations modeling to examine the mediating role of procedural justice in the relationships between promotion decisions and organizational commitment and between promotion decisions and intent to leave the organization. 156 managers and executives in Italian subsidiaries of two large multinational organizations in the chemical industry were surveyed about their career history within the organization and their reactions to promotion decisions over an 8-year period. The results showed that promotion decisions influenced feelings of organizational commitment through perceptions of procedural justice in promotion decision-making processes. The theoretical and practical implications of the study's findings are discussed.
\end{abstract}

Keyword procedural justice - promotion decisions - careers

\footnotetext{
${ }^{1}$ This research was supported by the Italian Ministry of University and Scientific Research (MURST). A previous version of this paper was presented at the 2000 Academy of Management meetings in Toronto and published in the Best Paper Proceedings. We would like to thank Paula Caliguiri, Jason Shaw, M. Susan Taylor, and two anonymous Academy reviewers for their helpful suggestions on prior drafts of this article.
} 
Promotion decisions are of the utmost importance to organizations and employees. From an organizational point of view, the quality of future management depends upon the quality of promotion decisions (London \& Stumpf, 1986). Promoting the best people will allow the company to preserve its competitive advantage through competent people who are skilled at making strategic decisions. From an employee point of view, promotions offer individuals tangible and intangible rewards - e.g., status, power, compensation, challenging work, responsibility, etc.- - and are hence a powerful source of motivation and satisfaction (Campbell, Dunnette, Lawler, \& Weick, 1970; Igbaria \& Greenhaus, 1992; Rosenbaum, 1984). The presence of career paths leading to a series of promotions and new positions also represents an important extrinsic reward for employees (Rhodes \& Doering, 1983). Thus, opportunities for career advancement are a relevant and critical part of organizations' incentive and reward systems (Bardwick, 1986).

Despite the importance of promotions for organizations and employees, promotion processes have been fraught with difficulties. Promotions, here defined as upward movements in an organization's hierarchy (Medsker \& Berger, 1990), have been constrained in organizations, as higher level positions are limited in number due to the pyramidal structure of traditional organizations. More recently, career experts have pointed out that after the restructuring, downsizing, and delayering that has affected most large companies in the last two decades (Casio, 2002), a vertical career has become even more difficult. In addition, slower organizational growth has aggravated the problem, and career management has become a very complex task for human resource managers (Evans, Gunz, \& Jalland, 1997). As a result, managers are experiencing longer job tenures or longer tenures at the same hierarchical level.

Because career progression is seen as one of the most important organizational rewards, longer job tenures are perceived as a violation of the psychological contract with negative consequences in terms of commitment, intent to stay, turnover, and other important attitudes and behaviors (Taylor, Audia, \& Gupta, 1996). Research has shown that a failure to be promoted or a lack of career prospects is associated with lower organizational commitment, job and career satisfaction, and higher withdrawal intentions, turnover, and absenteeism (De Souza, 2002; Igbaria \& Greenhouse, 1992; Johnston, Griffeth, Burton, \& Carson, 1993; Lam \& Schaubroeck, 2000; Quarles, 1994; Schwarzwald, Koslowsky, \& Shalit, 1992). Thus, in this context of reduced vertical mobility, the challenge for companies is to keep employees committed, satisfied, and in the organization regardless of promotion outcomes.

To address this challenge, some scholars have proposed trying to change the concept of career in managers' minds so that it is not defined by upward movement in the hierarchy (e.g., Brousseau, Driver, Eneroth, \& Larsson, 1996; Hall, 1986). However, such efforts may not be effective or may take too long to implement. Other scholars have proposed that attitudes and behavior that might otherwise result from an unfavorable organizational decision (e.g., a nonpromotion) may operate through perceptions that the decision process was fair (e.g., Brockner et al., 1994; Folger \& Konovsky, 1989), as research demonstrates that fairness influences decision acceptance (see Greenberg, 1996). Researchers have examined the role of fairness in different administrative decisions, such as compensation decisions (Folger \& Konovsky, 1989), layoffs and terminations (Brockner et al., 1994), performance appraisals (Greenberg, 1986; Taylor, Tracy, Renard, Harrison, \& Carroll, 1995) and employee selection processes (Gilliland, 1993, 1994; Singer, 1993)—many decisions that influence or are influenced by promotion decisions. The results of such research have generally shown that positive career outcomes enhance individuals' perceptions of the fairness of the process. Equally important, various studies have provided evidence of a positive relationship between justice judgments and individual affective and behavior outcomes (for a review, see Colquitt, Conlon, Wesson, 
Porter, \& Ng, 2001). Although the findings of this research generally suggest that organizational fairness in decision-making processes may encourage employees' acceptance of and positive reactions to many types of organizational decisions, little research has studied the role of justice in the context of promotion decisions. Moreover, few studies in promotion contexts have explored employee perceptions of promotion systems-specifically, the fairness of promotion processes - as a linkage between employee career outcomes and their attitudes and behaviors.

Building on prior career and justice research, we explore the mediating role of procedural justice in the relationship between promotion decisions and individual attitudes. Taking into account managers' career histories, we explore the cumulative effects of promotion decisions and the perceived fairness of such decisions. Further, because research has shown perceptions of fairness in decision-making processes to influence employees' acceptance of organizational decisions, we also examine relationships between fairness, organizational commitment, and intent to leave the organization. We investigate these relationships in an international context - Italian subsidiaries of two multinational chemical companies, which may be characterized by traditional organizational structures and internal career ladders. 


\section{CONCEPTUAL BACKGROUND AND HYPOTHESES}

\section{Current Research on Promotion Decisions}

Much of the research on promotion decisions has focused on the effects of employee characteristics on promotion decisions. For example, studies have shown demographic characteristics, such as race (Powell \& Butterfield, 1997), gender (Blum, Fields, \& Goodman, 1994; Ohlott, Ruderman, \& McCauley, 1994), and physical attractiveness and age (Morrow, McElroy, Stamper, \& Wilson, 1990) to influence promotion. In addition, research has highlighted the effects of individual characteristics, such as performance and potential, on promotion decisions (Ruderman, Ohlott, \& Kram, 1997). Other research has considered the impact of promotion on attitudes and behaviors using several proxies for actual promotions, such as promotion satisfaction (Bartol, 1979; Mobley, Horner \& Hollingsworth, 1978; Quarles, 1994) and the availability of promotional opportunities or career prospects (Igbaria \& Greenhouse, 1992; Marsh \& Mannari, 1977; Quarles, 1994). In these studies, positive relationships were found for job and career satisfaction (Bartol, 1979; Igbaria \& Greenhouse, 1992; Quarles, 1994), and for organizational commitment among supervisors (Quarles, 1994). Similarly, studies of promotion or advancement proxies have suggested negative relationships with turnover intentions and voluntary turnover (Carson, Carson, Griffeth, \& Steel, 1994; Porter \& Steers, 1973; Price, 1977; Stroh, Brett, \& Really, 1996). Despite these findings between promotion decisions and employee outcomes, the promotion measures included in many of these studies were perceptual, which limit the conclusions that can be drawn from the studies' findings.

Some research has considered employees' reactions to actual promotion decisions. For example, Johnston and colleagues (1993) used a longitudinal quasi-experimental design to investigate attitudes of promoted and non-promoted employees. Promoted employees demonstrated a higher level of commitment (or a lower decrease over time) and lower intent to leave (or a lower increase over time) than did non-promoted employees. Similarly, in a study designed to examine behavioral differences between male and female managers, the results showed a negative relationship between actual promotions and voluntary turnover (Lyness \& Judiesh, 2001). Schwarzwald et al. (1992) also compared attitudes and behaviors of managers after promotion decisions were made. Consistent with the results of other studies reviewed here, failure to be promoted was associated with decreases in organizational commitment and increases in absenteeism. However, the findings of this study also highlighted an important relationship between non-promotion and feelings of inequity, which suggests that employee perceptions of justice may help to explain the negative consequences resulting from non-promotion decisions.

\section{Fairness in Promotion Decisions}

Researchers have the examined the role of fairness in the context of human resource management, including compensation systems (Folger \& Konovsky, 1989), downsizing processes (Brockner et al., 1994), performance evaluation (Greenberg, 1986; Taylor et al., 1995) and selection systems (Gilliland, 1993, 1994; Singer, 1993). Although several studies have examined the effects of selection decisions on employee justice reactions (Gilliland, 1993, 1994), little attention has been given to the role of justice in promotions, which are considered to be a form of employee selection. Some research has attempted to establish a link between promotions and justice by focusing on employees' perceptions of fairness as a consequence of promotion systems. For example, research examining the structure of promotion systems suggests that employee perceptions of fairness are influenced by the type 
of criteria used to make promotion decisions (Kaplan \& Ferris, 2001; Pearce, Branyiczki, \& Bakacsi, 1994), Similarly, a study conducted by McEnrue (1989) to understand factors that enhance perceptions of fairness regarding promotion practices focused on the procedural elements of promotion decisions, including competency-oriented promotion criteria, welldefined promotion paths, and information received about the promotion process. The results demonstrated that promotion criteria and paths were significantly related to the perceived fairness of promotion decisions.

More recently, research has attempted to explore fairness as a characteristic of promotion systems and processes that influences employee attitudes. For example, a study by Lemons and Jones (2001) examined procedural justice in promotion decisions although justice was explored as an antecedent to organizational commitment. Using a sample of adult students, who were surveyed about the fairness of their companies' procedures used to determine promotions, the authors found a direct relationship between the perceived fairness of promotion decision systems and commitment. Researchers have also suggested that justice plays a role in the relationship between promotion decisions and employee reactions given that employees are likely to have positive perceptions of their organization and organizational justice when they receive rewards, such as promotions, which subsequently translates into higher levels of organizational attachment (Arvey \& Sackett, 1993; Beehr, Taber \& Walsh, 1980; De Souza, 2002). Along these lines, career mobility research offers perceptions of an organization's equity and justice mechanisms as an explanation for the relationship between promotion opportunity and organizational commitment (Halaby \& Sobel, 1979).

Overall, the findings of research to date highlight procedural justice as both a reaction to promotion decisions and an antecedent to other employee reactions. However, our understanding of the linkages between promotion decisions, justice and employee outcomes is limited given a lack of research in promotion contexts as well as research measuring the effects of actual promotion decisions. Because research provides evidence of direct relationships between fairness and employee attitudes and behavior and suggests that procedural justice in promotion decisions may influence employee reactions to such decisions, fairness in promotion systems may serve as a critical explanatory variable in the relationship between promotion decisions and employee attitudes. Despite the suggested mediating role of procedural justice, no studies have tested this three-step model. We attempt to advance current knowledge on promotion decisions and organizational justice by investigating the relationships between promotion decisions, procedural justice, and organizational commitment and turnover intentions.

\section{Hypothesis Development}

Given that research has demonstrated a relationship between promotion decisions and procedural justice and between perceived justice and organizational commitment, we argue that procedural justice perceptions may be responsible, in part, for the effects of promotion decisions on organizational commitment and turnover intentions. Research shows that the structure and/or characteristics of promotion systems influence perceptions of procedural justice (Kaplan \& Ferris, 2001; McEnrue, 1989; Pearce et al., 1994). In addition, organizational justice research has shown consistent relationships between perceptions of procedural justice and various individual work outcomes-specifically, organizational commitment. According to the group value model of procedural justice, fair procedures are believed to affirm an individual's status in a group, thereby strengthening that individual's level of identification with, and attachment to, the group (Lind \& Tyler, 1988). Because fair organizational processes are more likely to protect and/or promote an individual's interests in an organization, such processes should enhance the degree of attachment to the organization 
(Konovsky, Folger, \& Cropanzano, 1987). Accordingly, organizational justice studies have shown that perceptions of procedural justice strengthen employees' organizational commitment (Brockner, DeWitt, Grover, \& Reed, 1990; McFarlin \& Sweeney, 1992). Research has also demonstrated a relationship between procedural justice and withdrawal (Colquitt, 2001; Colquitt et al., 2001).

Although promotion decisions may serve as a form of extrinsic reward and may convey important information to employees regarding their career prospects, thus influencing employees' attachment to an organization, such effects may occur through employee perceptions of fairness in promotion decision-making processes. Instrumental models of justice, which are based on social exchange theory (Blau, 1964; Thibaut \& Kelley, 1959), assume that people are interested in maximizing their self-interest (i.e., resources) when interacting with others (Thibaut \& Walker, 1975). Accordingly, such models suggest that people use information about procedures to make inferences about their longer term outcomes. Because fair decision-making procedures are considered to be indicative of the predictability and certainty of favorable outcomes, fair promotion decisions may suggest a greater likelihood of favorable future career and/or organizational outcomes (e.g., promotion, compensation, etc.). Thus, fairness in promotion decisions may enhance employees' attachment to an organization. Taking into account the outcomes of promotion decisions as well as individuals' career histories (rather than single promotion decisions), we offer the following hypotheses:

Hypothesis 1: Procedural justice perceptions will mediate the relationship between promotion decisions and organizational commitment.

Hypothesis 2: Procedural justice perceptions will mediate the relationship between promotion decisions and intent to leave the organization.

The impact of organizational commitment on turnover intentions and turnover, as a causal sequence, has been well documented in several studies, literature reviews and meta-analyses (see e.g. Cohen, 1993; Jaros, Jermier, Koehler \& Sincich, 1993; Tett \& Meyer, 1993). This impact emerges from both definitional and causal mechanisms. First, the experience of loyalty and a desire to stay with the company are generally considered to be a definitional element of the affective organizational commitment construct (Jaros et al., 1993; Mowday, Steers, \& Porter, 1979). Second, commitment to the organization is generally conceived to also include identification with the organization and willingness to expend extra effort on its behalf. It is reasonable to expect that such a level of caring will stimulate a desire to remain with the company, in part, perhaps, because a committed employee may have a dedicated interest in helping the organization to succeed. While the association between commitment and intent to remain with the company derives in part from conceptual overlap, it is well demonstrated that commitment does influence employee turnover intentions. To replicate the findings of prior research, we include a link between these variables in our proposed model.

Hypothesis 3: Organizational commitment will be negatively related to intent to leave the organization.

\section{The Research Context}

Although there are a few exceptions (Bagdadli, Solari, Usai, \& Grandori, 2003 ; Perrone, Neri, \& Chiaccherini, 2000), little career and justice research has been done in an Italian 
context. However, Italy represents an interesting context to investigate the relevance of fairness in promotion decisions for several reasons. The configuration of the Italian labor market represents a setting where vertical promotion in a single hierarchy is extremely important and employees might be more sensitive to internal promotion decisions. Although the situation has begun to change in the last few years (Bagdadli et al., 2003), the Italian labor market is ruled by a strict work law which reduces companies' flexibility and job mobility (Galli, 1996; Padoa Schioppa, 1993). Consequently, the labor market is characterized by organizational careers, or careers that unfold in a single employment setting (Arthur \& Rousseau, 1996). Careers in Italy, especially in the more traditional sectors, develop according to the internal labor market (ILM) model described by Doeringer and Piore (1971). Workers usually join a company at bottom-level positions and spend all their working life inside one company, following an internal career ladder. Interorganizational mobility is now more frequent (Bagdadli et al., 2003; Preti, 2001), especially for younger generations, people working in professional occupations and new sectors. However, in traditional sectors such as the textile and chemical sectors investigated in our research, career advancement is still conceived as a progression in the organizational hierarchy, which is important in Italy (Hofstede, 1980).

Cross-cultural research on procedural justice has been quite limited (Morris \& Leung, 2000); however, those studies investigating justice concepts across cultures have primarily involved Asian samples (McFarlin \& Sweeney, 2001; Morris, Leung, Ames, \& Lickel, 1999). As such, current thinking regarding the meaning of justice and subsequent reactions to organizational justice may not generalize to employees from societies that have cultural and/or economic characteristics that differ from those commonly found in North American and Asian societies. Studying procedural justice in an Italian context will allow an examination of the universality of this justice concept. In addition, this study allows an investigation of the cross-cultural generality of procedural justice consequences. 


\section{METHOD}

\section{Sample and Context}

We surveyed 214 middle managers in Italian subsidiaries of two large multinational organizations in the chemical industry. We surveyed the entire population of employees who were middle managers in 1991 in the first company and in 1993 in the second company, and who were still in both companies in 1999 . We chose 1991 and 1993 as the reference years for defining the population because company records showed that the average length of time a middle manager has to wait to become eligible for an executive position was 8 years in the first company and 6 years in the second company. The average voluntary turnover for the population of middle managers (not including retirements and relocations) was $3.1 \%$ per year for the time period of 1991-1999. In both companies, promotion policies were such that a promotion to the rank of "Executive" required the availability of an executive position rather than upgrading an existing job, so that employees performed the same duties but received a new title and higher pay. $20 \%$ and $25 \%$ of the middle managers in the two organizations held executive positions in 1999. Thus, considering steady growth in the industry during the 1990's, traditionally hierarchical organizational structures, and low levels of voluntary turnover, we can assume a promotion rate of approximately one in four middle managers.

We received 156 usable questionnaires, resulting in a response rate of $73 \%$. Questionnaires were distributed during work hours and respondents were provided with return envelopes to mail their completed questionnaires to the researchers. Individual code numbers to ensure anonymity identified each respondent. The sample was $63 \%$ male, had an average organizational tenure of 18.5 years and had an average age of 44.5 years. In addition, respondents were distributed across a variety of departments-e.g., Production (21\%), Commercial (25\%), Technical Services (9\%), and other (45\%).

We examined individuals' career histories rather than single promotion decisions. A career history can be characterized as successful or unsuccessful based on the specific institutional and organizational context (Derr, 1987; Derr \& Laurent, 1989). In Italy, a managerial career history can be defined as successful if the manager, after a certain period of time, receives a promotion to the rank of executive. Managers in Italy start their career as Quadri (an administrative position that corresponds to middle management), and after several promotions to higher categories of Quadri, may become Dirigenti (an administrative position that corresponds to executive). The career move between Quadri and Dirigenti is important given differences in total compensation, special retirement privileges, organizational status and involvement in decision-making processes.

\section{Measures}

Promotion Decision. One item was used to assess whether or not respondents received a promotion to executive. Responses were coded as " 0 " if a promotion to executive was not received and as " 1 " if a promotion to executive was received.

Procedural Justice. Based on Leventhal (1980) and Thibaut and Walker (1975), seven items were created to measure respondents' perceptions of procedural justice. Sample questions include: "Do you think that similar promotion procedures are applied to all potential promotion candidates in this organization?"; "Did you have the opportunity to propose or discuss your candidacy for promotion?"; and "Do you think decision-makers know what you are contributing to your unit and the organization?" Responses were measured on a seven- 
point scale ranging from "strongly disagree" and "strongly agree." The Cronbach alpha for this scale was .90 .

Organizational Commitment was measured using nine items contained in Mowday et al.'s (1979) short-form questionnaire. Sample items include: "I am willing to put in a great deal of effort beyond that normally expected in order to help this organization be successful" and "I find that my values and the organization's values are very similar." Responses were measured on a seven-point scale ranging from "strongly disagree" and "strongly agree." The Cronbach alpha was .89 .

Intent to Leave. Three items were derived from research by O'Reilly, Chatman and Caldwell (1991) to measure respondents' intent to leave the organization. Items included: "I often think of leaving this organization"; "I may look for a new job in the next year"; and "I intend to keep working in this organization for at least the next 3 years" (reverse-scored). Responses were measured on a seven-point scale ranging from "strongly disagree" and "strongly agree". The Cronbach alpha was .84.

Control Variables. We measured four control variables: gender, age, tenure and unit location. Previous research has shown demographic variables to be important predictors of at least one of the dependent variables included in this study (Taylor et al., 1996). Respondents were asked to indicate their age using five categories: "younger than 35," "36-41," "42-47, "48-53," and "older than 54." To assess tenure, respondents were asked to indicate how many years they had worked for the organization using six categories: "less than 12," "13-18," "1924," "25-30," "31-36" and "more than 37." Given that one of the sample companies has two main sites that differ in terms of culture and work opportunities, unit location was also included as a control variable. This variable was coded as a dichotomous variable representing location 1, which is situated in northern Italy where many companies and work opportunities are located, and location 2 , which is in a small provincial city where there are few work sites and job opportunities.

\section{Analyses}

We conducted structural equation modeling by using maximum likelihood estimation (EQS 5 for Windows; Benter \& Wu, 1995). As suggested by Brown and Cudeck (1993), we used several fit indexes in combination to provide a complete assessment of model adequacy. More specifically, we used comparative fit index (CFI), incremental fit index (IFI), and root-meansquare error of approximation (RMSEA). Models resulting in CFI and IFI values of .90 or higher are considered acceptable (Bagozzi \& Yi, 1988). For the RMSEA index, values below .08 are considered indicative of good fit (Brown \& Cudeck, 1993).

Because an adequate fit does not necessarily mean a given model is the best explanation of the relationships among the constructs, we developed and tested a theoretically defensible alternative model to address model suitability (Anderson \& Gerbing, 1988). Contrary to the hypothesized model, the alternative model proposed that the proposed relationships between promotion decisions, organizational commitment and intent to leave the organization are only partially mediated by procedural justice. To compare the hypothesized model to the alternative model, we used the sequential chi-square difference test. The sequential chi-square difference test $\left(\Delta \chi^{2}\right)$ is used to assess changes in fit associated with models which have a nested or hierarchical relationship (Loehlin, 1992). A nested model is considered more suitable if its chi-square value is not statistically significantly worse compared with the less parsimonious model in which it is nested (Loehlin, 1992). 


\section{RESULTS}

Means, standard deviations and correlations of all variables included in the analyses are included in Table 1. Scale reliabilities are provided in parentheses on the diagonal of Table 1. All scale reliabilities are well above the .70 threshold recommended by Nunnally (1978).

Table 1 Means, Standard Deviations, and Correlations for all Variables Used in Study

\begin{tabular}{|l|l|l|l|l|l|l|l|l|l|l|}
\hline Variable & $\mathbf{M}$ & SD & $\mathbf{1}$ & $\mathbf{2}$ & $\mathbf{3}$ & $\mathbf{4}$ & $\mathbf{5}$ & $\mathbf{6}$ & $\mathbf{7}$ & $\mathbf{8}$ \\
\hline 1. Gender & .02 & .14 & - & & & & & & & \\
\hline 2. Age & 3.10 & 1.18 & -.10 & - & & & & & & \\
\hline 3. Tenure & 2.67 & 1.55 & -.08 & $.82^{* *}$ & - & & & & & \\
\hline 4. Location & 1.88 & .71 & -.01 & .12 & .10 & - & & & & \\
\hline 5. Promotion & .26 & .43 & .09 & -.10 & -.12 & -.01 & - & & & \\
\hline 6. Procedural justice & 3.71 & 1.17 & -.02 & .01 & .07 & .07 & $.28^{* *}$ & $(.90)$ & & \\
\hline 7. Commitment & 4.78 & .94 & -.03 & .09 & .15 & .08 & $.21^{*}$ & $.59^{* *}$ & $(.89)$ & \\
\hline 8. Intent to leave & 3.19 & 1.41 & .01 & $-.39^{* *}$ & $-.39^{* *}$ & -.09 & -.13 & $-.39^{* *}$ & $-.62^{* *}$ & $(.84)$ \\
\hline
\end{tabular}

Note. $\mathrm{N}=156$. Reliabilities for scales are indicated in parentheses along the diagonal. $* \mathrm{p}<.01$; $* * \mathrm{p}<.001$.

We used linear regression to analyze the effects of the control variables on the study's variables of interest. The results for procedural justice $[\mathrm{F}(4,148)=.81, \mathrm{~ns}]$ and commitment $[\mathrm{F}(4,144)=1.30, \mathrm{~ns}]$ showed that the control variables did not significantly influence these variables. However, the results for the model predicting intent to remain with the organization $[F(4,147)=6.96, p<.001]$ showed that age $(\beta=-.42, p<.001)$ significantly influenced the dependent variable. More specifically, older employees had a higher intent to remain with the organization than did younger employees. Given the effects of age on intent to remain, we included this relationship in the structural model to control for these effects. No significant differences in responses were found across companies or departments included in the sample.

Hypotheses 1 and 2 predicted that the relationships between promotion and organizational commitment and between promotion and intent to leave the organization, respectively, would be mediated by perceptions of procedural justice. Using the two-step approach to structural equation modeling (Anderson \& Gerbing, 1988), we assessed the adequacy of the measurement properties of the hypothesized model prior to considering the adequacy of hypothesized structural relationships between constructs. After this two-step approach, we compared the fit of the hypothesized model to that of an alternative model to give a clearer picture of the suitability of the relationships hypothesized. The initial measurement model was established with three latent factors (procedural justice, organizational commitment, and intent to leave) each represented by their expected multi-item indicators. For purposes of the measurement model, all factors and measured variables were allowed to covary freely. The test of the initial measurement model $\left(\chi^{2}=263.05,149 \mathrm{df}\right)$ resulted in normed fit indexes which indicated an adequate fit to the data $(\mathrm{CFI}=.93$, IFI $=.93$, RMSEA $=.05)$. The paths from latent constructs to individual indicators were all significant $(p<.05)$. with standardized loadings ranging from .39 to .90 . 
As the second step of model testing, we imposed a structural model on the initial measurement model by replacing covariances with causal paths according to the hypothesized relationships, as represented by the solid line paths in Figure 1. As predicted by the hypotheses, direct paths were added from promotion to procedural justice, from procedural justice to commitment and intent to leave, and from commitment to intent to leave. The fit indexes for the hypothesized model $\left(\chi^{2}=317.92,186 \mathrm{df}\right)$ indicated that this model reached an acceptable level of fit $(\mathrm{CFI}=.92, \mathrm{IFI}=.93, \mathrm{RMSEA}=.07)$. Consistent with prior research the path from commitment to intent to leave was significant $(\mathrm{p}<.01)$. In addition, the paths from promotion to procedural justice and from procedural justice to commitment were significant $(\mathrm{p}<.01)$. Therefore, hypothesis 1 was supported. As shown by the results, the path from procedural justice to intent to leave was not significant. Therefore, hypothesis 2 was unsupported. Consistent with the results of prior research, the path from organizational commitment to intent to leave was significant, thus supporting hypothesis 3 . Overall, the percent of variability in procedural justice, commitment and intent to leave explained by the model is $9.4 \%, 44.3 \%$, and $67.8 \%$, respectively.

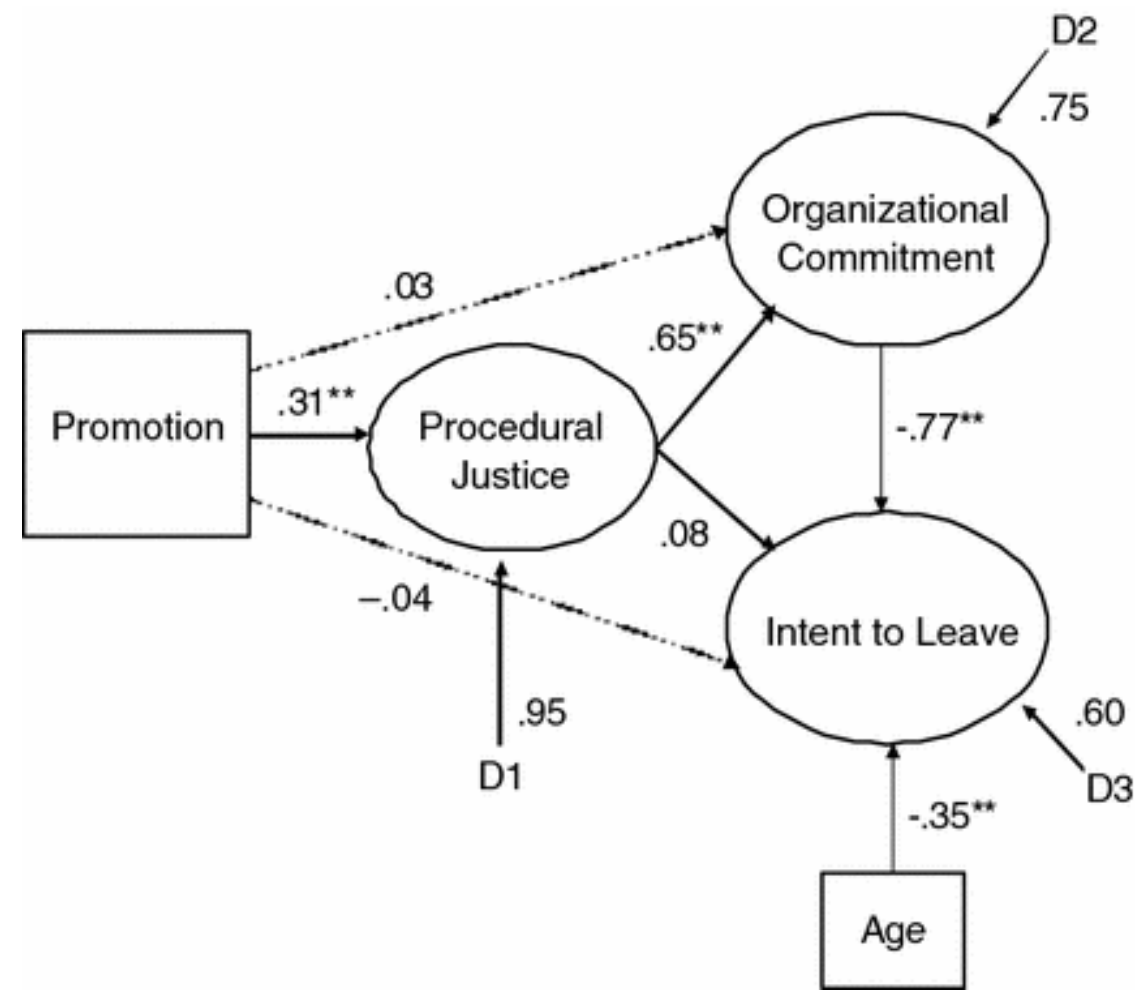

Figure 1 Hypothesized Model, Paths Added to Test Alternative Model, and Standardized Paths for Best Fitting Model. Standardized Path Values are from Hypothesized Model. Solid Lines Represent Hypothesized Model. Dashed Lines Represent Paths Added to Test Alternative Model. ** $\mathrm{p}<.01$

To assess the suitability of this hypothesized model, we also tested an alternative model that added direct paths from promotion to commitment and from promotion to intent to leave (see Figure 1, dashed lines). This alternative model predicts that procedural justice is a partial mediator of the hypothesized relationships. The test of this alternative model $\left(\chi^{2}=316.71\right.$, $184 \mathrm{df})$ suggested that the model provided an adequate fit to the data (CFI $=.92$, IFI $=.92$, RMSEA = .07). However, on the basis of the sequential chi-square different test, the hypothesized model could not be differentiated from the alternative model, $\Delta \chi^{2}$ (2, $\mathrm{N}=156)=1.21$, ns. The results showed that the path from promotion to procedural justice and from procedural justice to commitment remained significant $(\mathrm{p}<.01)$, whereas the direct paths from promotion to commitment and from promotion to intent to leave were not significant. Because the hypothesized model is nested within this alternative model, 
comparisons of model fit showed that the hypothesized model provided a more suitable and parsimonious explanation of the relationships among the data. Overall, the percent of variability in procedural justice, commitment and intent to leave explained by the model is $9.3 \%, 43.7 \%$, and $64.5 \%$, respectively. 


\section{DISCUSSION}

This study investigated the mediating role of procedural justice in the relationships between promotion and organizational commitment and between promotion and intent to leave the organization. We build on current career research which focuses on the availability of promotional opportunities or career prospects and their influence on employee outcomes to investigate direct relationships between promotion decisions and employee reactions to such decisions. Consistent with the results of prior research examining the effects of actual promotion decisions (Johnston et al., 1993), tests of our hypothesized model highlighted a positive association between promotion and organizational commitment to the organization. However, a direct relationship between these variables was not found. Instead, the results showed that perceptions of procedural justice in promotion processes completely mediated the promotion-commitment relationship such that there was no significant direct relationship when perceptions of procedural justice were controlled.

In much organizational research, there has been an emphasis on outcomes and a pervasive belief that attitudes and behavior are much more strongly determined by rewards than is in fact the case (Lind \& Tyler, 1988). However, the results of this study suggest that reactions to procedures are a significant factor in determining organizational commitment. Although employees may expect and value promotions through their career histories, the findings suggest that organizations may be more likely to maintain employee commitment when the procedures surrounding promotion decisions are perceived as fair. Thus, perceived procedural justice may be responsible, at least in part, for promotion effects on commitment and may clarify the findings of prior research.

Contrary to the hypothesis, procedural justice was not found to mediate the relationship between promotion and intent to leave the organization. Given lack of support for a direct link between procedural justice and intent to leave, the results may suggest that the influence of perceived fairness in organizational promotion systems on employee turnover intentions may operate through other mechanisms. In the test of our hypothesized model, which included a direct link between organizational commitment and intent to leave, the results instead showed an indirect effect of procedural justice on turnover intentions through organizational commitment. More specifically, employees that perceived promotion decisions as fair were more likely to be committed to the organization, and subsequently had a lower intention to leave the organization. Thus, the effects of promotion decisions on employee turnover intentions may be explained through the effects of such decisions on both procedural justice perceptions and organizational commitment.

The findings of this study have important managerial implications. Given the importance of promotion yet a trend of shrinking promotion opportunities (due to organizational structure characteristics), the results suggest that fairness in promotion decision-making processes may be an important managerial tool in influencing employee reactions to promotion decisions. Because many companies cannot promote all employees to higher organizational levels, they can maintain positive employee attitudes and behaviors by ensuring that procedural elements of career systems are perceived as fair. More specifically, companies undergoing restructuring and delayering, which subsequently provide reduced mobility opportunities for their managers, can rely on procedural justice in career decisions to avoid decreases in beneficial attitudes and behaviors. Furthermore, procedural justice may make waiting for promotions less of a penalty for effective managers, and may provide them opportunities to confirm their efficacy and to become candidates for future promotions. What is important to note is that while a company cannot control the economic environment or an economic crisis, it can be in control of variables such as the fairness of its systems. Companies that put effort into 
improving the fairness of the promotion procedures and making employees aware that fairness standards were upheld in decision-making processes may be able to keep employees committed to, and remaining in, the organization. Such implications are particularly important for companies operating in growth environments, where the biggest problem is retention of talent.

There are limitations to this study. First, the data do not represent true longitudinal data and therefore, may have been influenced by common method variance. Research using longitudinal data would help to further clarify the role of procedural justice in the relationships between promotion decisions and employee outcomes. Second, given that the research was conducted in an international context, there may have been cultural values that influenced the relationships between the hypothesized variables. Accordingly, exploring the role of procedural justice in promotion decisions within different contexts may show more complex relationships between the variables of interest. Future research is needed to examine other possible mediators or moderators in the hypothesized relationships or to establish the validity of these results in different contexts. Third, the study focused only on employee perceptions of procedural justice in promotion decisions although organizational justice research supports fairness as a multi-dimensional construct (Colquitt, 2001). Future research investigating the roles of distributive and interactional justice in promotion processes and decisions is needed.

Because the tests of our hypothesized model did not show a direct relationship between promotion decisions and intent to leave the organization, the results may suggest that single promotion decisions (rather than promotions throughout one's career history) may have a greater impact on employees' intentions to leave organizations. Alternatively, the results may suggest that promotion decisions have a greater influence on actual turnover. Given that our data were collected among the managers who still remained in their respective companies in 1999, employees who did not accept non-promotion decisions may have left the organization. As shown by our data, approximately 30 managers, who left their organizations during the research period, were unable to be reached. Thus, future research should investigate the mediating role of procedural justice in the relationship between promotion decision and actual turnover.

This study makes several theoretical contributions, as it represents a first attempt to empirically investigate procedural justice as a mediator of the relationships between promotion decisions and employee outcomes. This study integrates the career and organizational justice literatures and highlights a critical link between these two bodies of research. Further, it extends current findings in both of these literatures by examining the effects of both positive and negative decisions throughout employees' career histories and by investigating the meaning of procedural justice in a non-U.S. or non-Asian context. Most importantly, it establishes the role of fairness in promotion decisions and sheds some additional light on the black box, or intermediate linkages, linking promotion systems and employee reactions. 


\section{References}

Anderson J., Gerbing D., 1988. Structural equatio n modeling in practice: A review and recommended two-step approach Psychological Bulletin 103: 411-423

Arthur M. B., Rousseau D. M., 1996. Introduction: The boundaryless career as a new employment principle In Arthur M. B., Rousseau D. M., (Eds.), The boundaryless career: A new employment principle for a new organizational era Oxford University Press New York

Arvey R. D., Sackett P. R., 1993. Fairness in selection: Current developments and perspectives In Schmitt N., Borman W. C., (Eds.), Personnel selection in organizations Jossey Bass San Francisco, CA

Bagdadli S., Solari L., Usai A., Grandori A., 2003. The emergence of career boundaries in unbounded industries: Career odysseys in the Italian new economy International Journal of Human Resource Management 14: 788-808

Bagozzi R. P., Yi Y., 1988. On the evaluation of structural equation models Journal of the Academy of Marketing Science 16: 74-94

Bardwick J. M., 1986. The plateauing trap Bantam Books New York

Bartol K., 1979. Individual versus organizational predictors of job satisfactions and turnover among professionals Journal of Vocational Behavior 15: 55-67

Beehr T. A., Taber T. D., Walsh J. T., 1980. Personnel mobility channels: Criteria for intraorganizational mobility Organizational Behavior and Human Performance 26: 250-260 Bentler P. M., Wu E. J. C., 1995. EQS for Windows user's guide Multivariate Software Encino, CA

Blau P. M., 1964. Exchange and power in social life Wiley New York

Blum T. C., Fields D. L., Goodman J. S., 1994. Organizational level determinants of women in management Academy of Management Journal 37: 241-268

Brockner J., DeWitt R. L., Grover S., Reed T., 1990. When it is especially important to explain why: Factors affecting the relationship between managers' explanations of a layoff and survivors' reactions to the layoff Journal of Experimental Social Psychology 26: 389407

Brockner J., Konovsky M. A., Cooper-Schneider R., Folger R., Martin C., Bies R. J., 1994. Interactive effects of procedural justice and outcome negativity on victims and survivors of job loss Academy of Management Journal 37: 397-409

Brousseau K. R., Driver M. J., Eneroth K., Larsson R., 1996. Career pandemonium: Realigning organizations and individuals Academy of Management Executive 10: 52-67

Brown M. W., Cudeck R., 1993. Alternative ways of assessing model fit In Bollen K. A., Long J. S., (Eds.), Testing structural equation models Sage Newbury Park, CA 136-162

Campbell J. P., Dunette M. D., Lawler E. E., Weick K. E., 1970. Managerial behavior, performance, and effectiveness McGraw Hill New York

Carson P. P., Carson K. D., Griffeth R. W., Steel R. P., 1994. Promotion and employee turnover. Critique, meta-analysis, and implications Journal of Business and Psychology 8: 455-466

Casio W. F., 2002. Strategies for responsible restructuring Academy of Management Executive 16: 80-91

Cohen A., 1993. Organizational commitment and turnover: A meta-analysis Academy of Management Journal 36: 1140-1157

Colquitt J. A., 2001. On the dimensionality of organizational justice: A construct validation of a measure Journal of Applied Psychology 86: 386-400

Colquitt J. A., Conlon D. E., Wesson M. J., Porter C. O., Ng K. Y., 2001. Justice at the millennium: A meta-analytic review of 25 years of organizational justice research Journal of Applied Psychology 86: 425-445 
Derr C. B. 1987. Managing high potentials in Europe: Some cross-cultural findings European Management Journal 5:72-80

Derr C. B., Laurent A., 1989. The internal and external career In Arthur M. B., Hall D. T., Lawrence B. S., (Eds.), Handbook of career theory Cambridge University Press Cambridge, MA 454-471

De Souza G., 2002. A study of the influence of promotions on promotion satisfaction and expectations of future promotions among managers Human Resource Development Quarterly 13: 325-340

Doeringer P. B., Piore M. J., 1971. Internal labor markets and manpower analysis D.C. Heath Lexington, MA

Evans M. G., Gunz H. P., Jalland R. M., 1997. Implications of organizational downsizing for managerial careers Canadian Journal of Administrative Sciences 14: 359-371

Folger R., Konovsky M. A., 1989. Effects of procedural and distributive justice on reactions to pay raise decisions Academy of Management Journal 32: 115-183

Galli G., 1996. La mobilità della società italiana SIPI Roma

Gilliland S. W., 1993. The perceived fairness of selection systems: An organizational justice perspective Academy of Management Review 18: 694-734

Gilliland S. W., 1994. Effects of procedural and distributive justice on reactions to a selection system Journal of Applied Psychology 79: 691-701

Greenberg J., 1986. Determinants of perceived fairness of performance evaluations Journal of Applied Psychology 71: 340-342

Greenberg J., 1996. The quest for justice: Essays and experiments Sage Publications Thousand Oaks, CA

Halaby C. N., Sobel M. E., 1979. Mobility effects in the workplace American Journal of Sociology 85: 385-416

Hall D. T., 1986. Career development in organizations Jossey-Bass San Francisco

Hofstede G., 1980. Culture's consequences: International differences in work-related values Sage Beverly Hills, CA

Igbaria M., Greenhouse J. H., 1992. The career advancement prospects of managers and professionals: Are MIS employees unique? Decision Sciences 23: 478-499

Jaros S. J., Jermier J. M., Koehler J. W., Sincich T., 1993. Effects of continuance, affective, and moral commitment on the withdrawal process: An evaluation of eight structural equation models Academy of Management Journal 36: 951-995

Johnston M. W., Griffeth R. W., Burton S., Carson P. P., 1993. An exploratory investigation into the relationship between promotion and turnover: A quasi-experimental longitudinal study Journal of Management 19: 33-49

Kaplan D. M., Ferris G. R., 2001. Fairness perceptions of employee promotion systems: A two-study investigation of antecedents and mediators Journal of Applied Social Psychology 31: 1204-1222

Konovsky M. A., Folger R., Cropanzano R., 1987. Relative effects of procedural and distributive justice on employee attitudes Representative Research in Social Psychology 17: $15-24$

Lam S. S. K., Schaubroeck J., 2000. Reactions to being promoted and to being passed over: A quasi-experiment Academy of Management Journal 43: 66-78

Lemons M. A., Jones C. A., 2001. Procedural justice in promotion decisions: Using perceptions of fairness to build employee commitment Journal of Managerial Psychology 16: $268-280$

Leventhal G. S., 1980. What should be done with equity theory? In Gergen K. J., Greenberg M. S., Willis R. H., (Eds.), Social exchange: Advances in theory and research Plenum New York 27-55

Lind E. A., Tyler T. R., 1988. The social psychology of procedural justice Plenum New York 
Loehlin J. C., 1992. Latent variable models (2) Lawrence Erlbaum Hillsdale, NJ

London M., Stumpf S. A., 1986. Individual and organizational career development in changing times In Hall D.T., (Eds.), Career development in organizations Jossey-Bass San Francisco CA 21-49

Lyness K. S., Judiesch M. K., 2001. Are female managers quitters? The relationship of gender, promotions and family leaves of absence to voluntary turnover Journal of Applied Psychology 86: 1167-1178

Marsh R. M., Mannari H., 1977. Organizational commitment and turnover: A predictive study Administrative Science Quarterly 22: 57-75

McEnrue M. P., 1989. The perceived fairness of managerial promotion practices Human Relations 42: 815-827

McFarlin D. B., Sweeney P. D., 1992. Distributive and procedural justice as predictors of satisfaction with personal and organizational outcomes Academy of Management Journal 35: 626-637

McFarlin D. B., Sweeney P. D., 2001. Cross-cultural applications of organizational justice In Cropanzano R., (Ed.), Justice in the workplace: From theory to practice 2 Erlbaum Mahwah, NJ 67-95

Medsker G. J., Berger C. A., 1990. Toward a theory of career satisfaction: Development of construct and alternative models Paper presented at the annual meeting of the Academy of Management San Francisco

Mobley W. H., Horner S. O., Hollingsworth A. T., 1978. An evaluation of precursors of hospital employee Journal of Applied Psychology 62: 1-8

Morris M. W., Leung K., 2000. Justice for all? Progress in research on cultural variation in the psychology of distributive and procedural justice Applied Psychology An International Review 49: 100-132

Morris M. W., Leung K., Ames D. Lickel B., 1999. Views from inside and outside: Integrating emic and etic insights about culture and justice judgments Academy of Management Review 24: 781-796

Morrow P. C., McElroy J. C., Stamper B. G., Wilson M. A., 1990. The effects of physical attractiveness and other demographic characteristics on promotion decisions Journal of Management 16: 723-736

Mowday R. T., Steers R. M., Porter L. W., 1979. The measurement of organizational commitment Journal of Vocational Behavior 14: 224-247

Nunnally J. C., 1978. Psychometric theory McGraw-Hill New York

Ohlott P. J., Ruderman M. N., McCauley C. D., 1994. Gender differences in manager's development job experience Academy of Management Journal 36: 46-67

O'Reilly C. A., Chatman J., Caldwell D. E., 1991. People and organizational culture: A profile comparison approach to assessing person-organization fit Academy of Management Journal 34: 487-516

Padoa Schioppa F., 1993. Squilibri e rigidità del mercato del lavoro italiano. Angeli. Milano

Pearce J. L., Branyiczki I., Bakacsi G., 1994. Person-based reward systems: A theory of organizational reward practices in reform-communist organizations Journal of Organizational Behavior 15: 261-282

Perrone V., Neri M., Chiaccherini C., 2000. L'equità nelle organizzazioni: un'analisi empirica degli effetti sulla fiducia e sul coinvolgimento della risorsa umana In Maggi B., (Ed.), Le sfide organizzative di fine e inizio secolo Etas Milano, Italy

Porter L. W., Steers R. M., 1973. Organizational, work, and personal factors in employee turnover and absenteeism Psychological Bulletin 80: 151-176

Powell G. N., Butterfield D. A., 1997. Effect of race on promotions to top management in 
a federal department Academy of Management Journal 40: 112-128

Preti P. P., 2001. Cambiare azienda per fare carriera Egea Milano, Italy

Price J. L., 1977. The study of turnover Iowa State University Press Ames, IA

Quarles R., 1994. An examination of promotion opportunities and evaluation criteria as mechanism for affecting internal auditor commitment, job satisfaction and turnover intentions Journal of Managerial Issues 6: 176-194

Rhodes S. B., Doering M., 1983. An integrated model of career change Academy of Management Review 8: 631-639

Rosenbaum J. E., 1984. Career mobility in a corporate hierarchy Academic Press Orlando, FL

Ruderman M. N., Ohlott P. J., Kram K. E., 1997. Managerial promotions: The dynamics of men and women Center for Creative Leadership Greensboro, NC

Schwarzwald J., Koslowsky M., Shalit B., 1992. A field study of employees' attitudes and behaviors after promotion decisions Journal of Applied Psychology 77: 511-514 Singer M., 1993. Fairness in personnel selection: An organizational justice perspective Aldershot Avebury, England

Stroh L. K., Brett J. M., Really A. H., 1996. Family structure, glass ceiling, and traditional explanations for the differential rate of turnover of female and male manager Journal of Vocational Behavior 49: 99-118

Taylor M. S., Audia G., Gupta A. K., 1996. The effect of lengthening job tenure on managers' organizational commitment and turnover Organization Science 7: 632-648

Taylor M. S., Tracy K. B., Renard M. K., Harrison J. K., Carroll S. J., 1995. Procedural justice in performance appraisal: A field test of the due process metaphor for performance appraisal systems Administrative Science Quarterly 40: 495-523

Tett R. P., Meyer J. P., 1993. Job satisfaction, organizational commitment, turnover intention, and turnover: path analysis based on meta-analytic findings Personnel Psychology 46: 259-293

Thibaut J., Kelley H. H., 1959. The social psychology of groups Wiley New York

Thibaut J., Walker L., 1975. Procedural justice: A psychological analysis Lawrence Erlbaum Hillsdale, NJ 